\title{
Social and Environmental Accountability in Developing Countries
}

\author{
Ataur Rahman Belal Ph.D.
}

\section{Contact details}

Ataur Rahman Belal Ph.D.

Accounting Group

Aston Business School

Aston University

Birmingham B4 7 ET, UK

E-mail: a.r.belal@aston.ac.uk

Telephone: 00441212043031

Fax: 00441212044915

\section{Proposed citation}

Belal, A. (2015). Social and Environmental Accountability in Developing Countries. In D. Jamali, C. Karam and M. Blowfield (Ed.), Development-Oriented CSR, Vol 1: 153-166, Sheffield: Greenleaf Publishing.

\section{Short Biography}

Ataur Belal is a Reader [Associate Professor] and Head of Accounting Department at the Aston Business School, Aston University, Birmingham, UK. Currently he is joint editor of Advances in Environmental Accounting and Management and an Associate Editor of Accounting Forum. Ataur obtained his Ph.D. from the University of Sheffield, UK. 


\begin{abstract}
$\underline{\text { Abstract }}$
The principal aim of this chapter is to undertake a critical review of the social and environmental accountability of global business activities in developing countries. While global business activities have contributed to the economic development of developing countries they have many adverse social and environmental consequences which are often under-studied. I explore the role of accounting in making those consequences visible. The chapter, however, concludes that while social and environmental accounting has the potential to raise the visibility of social and environmental impacts of corporate activities it often fails to do so particularly under the current voluntary disclosure regime where corporations can choose what to report and how to report. This is even more pronounced in the developing countries because of their vulnerabilities arising from various social and environmental problems. The chapter argues for a case of 'surrogate accountability' as an alternative to the current corporate driven form of accountability.
\end{abstract}

\title{
$\underline{\text { Key words }}$
}

CSR, Social Accountability, Environmental Accountability, Surrogate Accountability, Developing Countries, Bangladesh

\section{Introduction}

The principal aim of this chapter is to undertake a critical review of the social and environmental accountability of global business activities in developing countries. These global business activities not only contribute to the socio-economic development of developing countries but also bring with them many adverse social and environmental consequences (Belal, Cooper, \& Roberts, 2013). I examine the role of accounting in making those consequences visible with a view to promote transparency and accountability of business activities (Cooper \& Owen, 2007; Medawar, 1976) in developing countries. I also highlight the corporate motivations for social and environmental accounting and accountability exercises. For this purpose I draw on the extant social and environmental accountability literature to achieve the aim and objective of this chapter.

The chapter is structured in six sections. In the next section I highlight the social and environmental consequences of global business activities in developing countries (Jamali, 2010; Jamali \& Mirshak, 2006). Here I argue that while these activities have brought in some benefits in the form of socioeconomic development (including employment and tax revenues) they have also created significant undesired social and environmental consequences (e.g. environmental pollution and negligence of various labour issues including health and safety) for the people and the environment of these developing countries (Derry, 2012). Section three articulates the need for corporate accountability for these social and environmental impacts (Belal et al., 2013). This is done based on work that has been carried out so far in the social and environmental accountability literature from the context of developing countries. Given the failure of the voluntary reporting regime to promote transparency and accountability, particularly in the context of developing countries, section four offers the potential of "surrogate accountability" as a possible way forward. Section five briefly explores the potential of development-oriented Corporate Social Responsibility (CSR). The final section summarises the discussion in the chapter and offers some concluding thoughts. 


\section{Social and Environmental Consequences of Global Business Activities in Developing Countries}

While globalisation and its principal agent multinational enterprises (MNEs) have created many opportunities in developing countries in terms of economic development, tax revenues for the national exchequer of the host government and employment generation they have also resulted in adverse social and environmental impacts. Eden and Lenway (2001) have referred to these impacts as the 'dark side' of globalisation. Given the vulnerability of developing countries (Belal et al., 2013) these impacts could be potentially very significant. The vulnerabilities of developing countries arise from widespread poverty, corruption, fragile natural environment and weak governance and regulatory system.

Global corporations are spreading around the world in search of efficiency and cost effective operations (Sikka, 2008). The destinations often include developing countries with exploitable resources (Sikka, 2011). Global capital is good at exploiting these resources located within the developing countries as a profitable venture. These resources can take the forms of oil and gas, mining and cheap labour (Sikka, 2011). However, the vulnerabilities of the developing countries are such that in that process the citizens of these countries and their livelihood might be endangered via adverse social and environmental impacts (Belal et al., 2013). I provide illustrative examples of these adverse consequences in the following paragraphs.

Many of these developing countries (for example, China, Bangladesh and Vietnam) have adopted an export led strategy to pursue their economic development objectives. After China, Bangladesh is known as the second largest exporter of garments and textile products. After its initial start in the late 1970s this is now a 20 billion USD industry with the potential to reach 36 to 42 billion USD by 2020 (McKinsey, 2011). There are 5000 factories in Bangladesh employing 3.6 million workers $90 \%$ of whom are women. More than $80 \%$ of total export proceeds of the country come from this sector (McKinsey, 2011). Thus economic contribution of the sector towards the national economy of Bangladesh is significant. However, even more significant is the adverse social and environmental impacts created from this export led economic growth. We now turn our attention to these impacts.

The appalling working conditions in the garment factories within the supply chains of large Western clothing retailers located in the poor developing countries like Bangladesh is well known and well documented. The health and safety of the workers is an issue of particular concern. In Bangladesh alone hundreds of workers died from health and safety related incidents. The latest incident took place on 24 April, 2013 which shook the world (Epstein \& Buhovac, 2014). On this day a building in Dhaka city, called Rana Plaza, collapsed ${ }^{1}$ killing over 1100 peoples and leaving hundreds more injured. Rana Plaza housed five garments factories which had supplied to a number of European and North American retailers including Walmart, Primark, C\&A, Benetton and Cato Fashions. This incident took place only five months after Tazreen Factory Fire incident which took 112 lives of garments workers. Tazreen is believed to supply goods for Walmart (New York Times, 10 December, 2012).

While the labour related issues in the Bangladeshi garments sector, such as child labour, forced labour, fair wages and health and safety, have attracted attention of the international media and other stakeholders environmental pollution created by the garments manufacturing activities have received less attention (Matin, 1995). A recent local newspaper report ran a story on the environmental pollution created by the Dhaka Export Processing Zone in Ashulia where most of the garment factories are located (Saha, 2014). The report suggests that environmental pollution from these factories has affected nearby village canals, created public health hazards for the local villagers and

\footnotetext{
${ }^{1}$ This is due to faulty structures of the building which housed these factories.
} 
other visible losses in the form of rusts on the roof top tins of the poor village homes. In a New York Times feature article on another industrial zone in the suburb (Savar area) of Dhaka where a number of garments factories are located Yardley (2013) noted that discharge of untreated wastes is causing major 'water pollution disaster', destroying the rice paddies. It is also reported that fish stocks are dying in the nearby water bodies.

Bangladeshi garments manufacturers supply to the international retailers mainly competing on price. The cheap labour cost is the main source of attractions for Bangladesh. Bangladesh is believed to have the lowest labour cost in the world with the monthly wages of a garments worker at roughly \$37 a month (New York Times, 24 April, 2013). However, cheap garment price enjoyed by the Western consumers came from the degradation of working conditions of desperately poor workers and critical environmental resources as made evident in the above paragraphs with clear examples.

Another example of major environmental degradation is the Hazaribagh area of Dhaka where 206 tanneries are located. The exports earnings from the leather sector are worth billion dollars desperately needed by the poor country. However, untreated toxic wastes discharged from these tanneries have created a major public health hazard in the area once known as thousands flowers (Hazaribagh) (Motlagh, 2013). The titles of two international media reports on these tanneries say it all: 'Hell for Leather: Bangladesh's Toxic Tanneries Ravage Lives and Environment' (Motlagh, 2013) and 'Bangladesh's toxic tanneries turning a profit at an intolerable human price' (Renton, 2012). According to Maurice of World Health Organisation (Maurice, 2001), 90\% of the workers of these tanneries die before the age of 50 due to gastrointestinal, dermatological and other diseases arising from the significant pollution caused by these tanneries. Children and adults work in these tanneries largely unprotected to supply cheap high-quality "Bengali black" leather which is in high demand from the European leather retailers and fashion designers (Renton, 2012). Millions of litres of largely untreated wastes passes through the neighbourhood, agricultural lands destroying the paddies and ultimately finds it way in one of the main rivers of the country - Buriganga. Due to pollution Buriganga has become 'clinically dead' destroying the livelihoods of the poor citizens of the country who used the river for fishing, boating and bathing (Belal, 2008; Belal \& Owen, 2007).

The ship breaking industry emerging on the shores of India, Pakistan and Bangladesh turns billions of dollars for the national economies. However, it comes at intolerable human and environmental costs. Ten kilometres long Massive Gadani ship-breaking yard in Pakistan is known as the world's largest ship-breaking yard. Miller (2013) reports that workers at Gadani toil for a mere $£ 2$ a day. The working conditions are reported to be inhumane and dangerous. Fatal incidents are common in the Bangladeshi ship breaking industry located in Chittagong. Widespread damage is reported to have caused to the local environments through effluent discharge from the ships and hazardous materials — like asbestos, PCB and lead leeching into the shore and the sea (EIU, 2012; Hossain \& Islam, 2006). In addition to earning billion dollars for the national coffer this industry meets the significant demands for metal in the growing construction industry of these nations.

In addition to the above labour intensive industries, natural resource based industries (for example, oil and gas, mining, etc.) are common in developing countries. Due to corruption, funding constraints and lack of expertise the governments of developing countries are often unable to extract these resources to the best advantage of its citizens. This desperate situation allows the multinational corporations to come in and exploit these resources in a way where commercial considerations lead to the negligence of the environmental, community and human rights impacts (Khavul \& Bruton, 2013; NewenhamKahindi, 2011; Sikka, 2011). Weak, often corrupt, regulatory and governance regimes in these countries mean that nation's interests are not always best served by the governments and MNEs involved in the exploration activities. 
One example here can be that of Magurcharra incident in Bangladesh which received comparatively less international attention. In this incident of gas blow out billions of dollars of natural gas were wasted and serious environmental damage was caused to the nearby neighbourhood and communities. In June 1997 during the process of gas exploration by the US oil company Occidental a gas well blew out. The massive blowout created havoc in Magurcharra and the nearby villages and communities. The flora and fauna of the nearby places including the Lawacharra Reserve Forest was destroyed. 96 acres of the Lawacharra forest was burnt and rare biodiversity of the adjoining areas was damaged by continuous forest fires for 17 days (Siddiqui, 2001). According to the The National Committee to Protect Oil-Gas-Mineral Resources and Port of Bangladesh, 245 billion cubic feet of gas was burnt in the explosion resulting in 9 billion Taka ${ }^{2}$ loss to the nation (The New Nation, $13^{\text {th }}$ June, 2006). While the full compensation is yet to be received the gas exploration activities in Bangladesh by the MNEs continue. In 2005 two similar incidents took place in Tangratila of Bangladesh while conducting exploration activities by a Canadian multinational company - NIKO (Islam \& Islam, 2011). The incidents resulted in the wastage of millions of cubic feet of gas which is valued at US\$50-60 million, according to one estimate (Nasreen, Mokaddem Hossain, \& Kumar Kundu, 2006, cited in Islam and Islam, 2011). Tens of thousands of villagers in the nearby areas had to flee their homes for fear of life. Ordinary people demonstrated on the street demanding compensation for the loss of homes and livelihoods. However, very little was paid in the form of compensation to the villagers and the state. Niko officials attempted to escape the compensation in collaboration with some corrupt government officials. Gas exploration by another US company Chevron in Bibiyana gas field met with local resistance by people who lost their lands receiving very little in return (Gardner, Ahmed, Bashir, \& Rana, 2012). Chevron's exploration activities in the environmentally sensitive areas of Bangladesh have received widespread criticism and resistance from affected people. However, their activities continue as of today resulting in significant social and environmental costs which is hardly accounted for. Table 1 provides a selective summary of the social and environmental consequences of global business activities in Bangladesh. The table captures the social and environmental consequences of global business activities in developing countries by exhibiting Bangladesh as a case in point/example.

\begin{tabular}{|l|l|}
\hline $\begin{array}{l}\text { Table 1: Social and Environmental Consequences of Global Business Activities: Summary } \\
\text { and A Case of Bangladesh }\end{array}$ \\
\hline Business Activity Types & Examples of Social and Environmental Consequences \\
\hline Garments manufacturing and export & $\begin{array}{l}\text { Poor working conditions, child labour, human rights } \\
\text { violation; health and safety concerns (e.g. Rana Plaza } \\
\text { factory building collapse noted above); environmental } \\
\text { degradation }\end{array}$ \\
\hline Leather processing and export & $\begin{array}{l}\text { Environmental pollution arising from toxic discharges; } \\
\text { extreme public health hazards (e.g. Hazaribagh tanneries) }\end{array}$ \\
\hline Emerging ship breaking industry & $\begin{array}{l}\text { Poor working conditions; health and safety concerns (e.g. } \\
\text { ship breaking industries in Chittagong) }\end{array}$ \\
\hline Natural resource extraction & $\begin{array}{l}\text { Environmental accidents leading to loss of local flora and } \\
\text { fauna (e.g. Magurcharra disaster); loss of local community } \\
\text { lands and homes during gas exploration process }\end{array}$ \\
\hline
\end{tabular}

The social and environmental consequences of global business activities are not limited to Bangladesh. The story is similar elsewhere. In Nigeria, Shell's oil exploration activities in Niger Delta led to significant environmental damage, displacement of the local people and the human rights

${ }^{2} 1$ US $\$=80$ Taka approximately. 
violations of the Ogoni people. Some of these companies are so powerful that even the host states are sometimes unable to hold them to account. Corporate accountability is even more difficult to achieve when some of these states are crippled by corruption and weak institutions (Sikka, 2011). Moreover, sometimes these developing nation states are smaller than these large corporations creating power differentials. For example, in 2011 the annual Gross Domestic Product (GDP) of Nigeria was US\$ 235.923 billion while the total revenue of Shell was US $\$ 484.480$ billion. The company ranked $26^{\text {th }}$ on the list of the World's Top 175 Economic Entities while Nigeria ranked only 52 (http://dstevenwhite.com/2012/08/11/the-top-175-global-economic-entities-2011, accessed on 12 May, 2014). Such disparity in power and size between the corporations and the host government indicates that some of these poor developing nation states are often unable to protect their own citizens' interests in various investments contracts agreed with these powerful corporations (Lauwo \& Otusanya, 2014).

In Tanzania gold mining activities by the multinational companies have displaced local communities, led to violation of human rights and significant impacts on the local natural environment (Gifford, Kestler, \& Anand, 2010; Lauwo \& Otusanya, 2014). Various tax incentives and stabilisation clauses inserted in the mineral development agreements (MDAs) have adverse social and environmental impacts. Lauwo \& Otusanya (2014) have examined the Tanzanian MDA of Barrick Gold Mining (a Canadian Multinational) and expressed concern about the lack of transparency in the process of signing the contract. Their study focused on Barrick's operations in Buzwagi Gold Mine (BGM) of Tanzania. Mining operations required eviction of local residents from their lands violating their human rights. It has also led to resistance movements, conflicts with the mining company and widespread health hazands arising from environmental pollution caused by heavy metals and hazardous chemicals. It has affected local residents' rights to clean environment and safe water supply. The terms and conditions of the MDA (including the stabilisation clauses) with Barrick constrained the ability of the Tanzanian state to uphold its' own citizens rights (Lauwo \& Otusanya, 2014).

The social and environmental consequences of global corporate activities in developing countries, as highlighted above, raise issues for serious concerns. These impacts are arising from the process of globalised production and exploration activities. How do we hold the global capital to account for these adverse social and environmental impacts? This is where accounting and accountability have a greater role to play. If we accept that global capital is responsible for these impacts then we could demand accountability thereof and discuss an appropriate form of accountability required to make global capital accountable to people. In the next section I discuss the possibilities of these accountabilities (or the lack of it).

\section{Corporate Social and Environmental Accountability in Developing Countries}

Traditionally, the discipline of accounting is pre-occupied with the economic performance of organisations. Traditional accounting model does not capture the social and environmental consequences highlighted in the previous section. By relaxing some of the constraints of traditional accounting model social and environmental accounting can have the emancipatory potential (Gallhofer, Haslam, Monk, \& Roberts, 2006) of promoting the visibility of social and environmental consequences arising from global corporate activities (Belal, 2008; Gray, Adams, \& Owen, 2014a; Unerman, 2003). The fundamental objective of social and environmental accounting is to enhance the transparency and accountability of organisations (Medawar, 1976). Thus, social and environmental accounting is linked to the discharge of accountabilities related to the social and environmental performance of organisations. This should empower the stakeholders affected by the adverse social and environmental performance of organisational activities and thereby could be considered as a 
mechanism for holding organisations to account. However, given the power differentials between organisations and the stakeholders to what extent the emancipatory potential of accounting can be realised is a moot question.

Publication of CSR reports ${ }^{3}$ by various organisations is a contemporary phenomenon and has become a mainstream activity amongst the larger corporations. According to the latest KPMG survey of CSR reporting (KPMG, 2013) 71\% of 4100 companies included in the survey have published such reports. This phenomenon is not only noticeable in developed countries but also in emerging and developing countries. KPMG survey has found significant growth in the reporting of Indian, Chinese and Taiwanese companies.

Most of these reports are published voluntarily. Why do they do so? A significant body of research exists which explored the underlying motivations for CSR reporting. A dominant explanation in the social and environmental accounting research is that corporations use CSR reports as a tool for legitimising their activities (Cho, 2009; Cho \& Patten, 2007; Deegan, 2002; Deegan, Rankin, \& Tobin, 2002; Kamal \& Deegan, 2013). Most of the researchers concluded that CSR reporting is an exercise aimed at the management of powerful stakeholders while it meant to be aimed at discharging accountability to all stakeholders irrespective of their power (Belal, 2002; Belal \& Owen, 2007; Cooper \& Owen, 2007).

Voluntary reporting regimes meant that corporations could cherry pick and choose what to report resulting in incompleteness of reporting. Incomplete reporting defeats the fundamental objectives of CSR reporting - transparency and accountability. Belal and Cooper (2011) observed that significant omission occurred in the CSR reporting of Bangladeshi companies on the issues of child labour, equal opportunities and poverty alleviation. They argued that these omissions might be deliberate attempts by business or an indication of their unwillingness to engage with issues of national and international significance.

These issues are not only significant in the national context of Bangladesh but also in many other developing countries. In the context of Tanzanian gold mining industries Lauwo \& Otusanya (2014) note that the issues of human rights abuse and serious environmental pollution have not been disclosed in the CSR reports of the mining company under study. Most of these issues affect poor and vulnerable stakeholders such as local villagers and community peoples in the neighbourhood where operations of global companies take place. These stakeholders bear the brunt of the 'dark side' of the globalised corporate activities and include the destitute workers of textile factories and shipyards, community peoples in the neighbourhood of Hazaribagh and Niger Delta and the villagers affected by the Tanzanian mining activities. They do not speak English nor do they have the powers to seek redress and hold these mighty corporations to account (Belal, Cooper \& Khan, 2015).

Corporate reporting of social and environmental performance have so far failed to deliver the desired level of transparency necessary to ensure accountability to the powerless vulnerable stakeholders noted above. Given the disparity in power these stakeholders themselves are unable to hold the

\footnotetext{
${ }^{3}$ It is also known as social reports, environmental reports and social and environmental reports. There are many other labels to it. Currently most reports are labelled as sustainability reports or integrated reports. CSR refers to the corporate commitment to conduct their operations in a social, ethical and environmental friendly manner. According to a Green paper published by European Commission (EC, 2001) it refers to "a concept whereby companies integrate social and environmental concerns in their business operations and in their interaction with their stakeholders on a voluntary basis". Corporations may undertake CSR activities but might not necessarily report those activities in the public domain. However, in recent times corporations have started to provide an account of their CSR activities via their websites and stand-alone CSR/sustainability reports. KPMG surveys periodically track such developments in reporting.
} 
corporations to account. Power and size of the large corporations, weak regulatory regimes and corruption in state governance result in unwillingness or inability of the developing country governments to reign in the activities of the global corporations (Lauwo \& Otusanya, 2014; Sikka, 2011).

\section{Surrogate Accountability and its Potential for Developing Countries}

The above discussion shows that corporate reluctance, unable governments and powerless stakeholders of developing countries do not provide much hope for social and environmental accountability of corporate activities under the current voluntary corporate reporting regime. However, there could be better hopes in alternative possibilities of providing 'counter accounts' from non-corporate sources such as civil societies including non-governmental organisations (NGOs), pressure groups and trade unions. In this context the concept of 'surrogate accountability' (Rubenstein, 2007) might be worthy of examination. According to Rubenstein (2007), it:

...involves an actor-a surrogate-who substitutes for accountability holders during one or more phases of the accountability process: setting standards, finding and interpreting information, and, most importantly, sanctioning the power wielder if it fails to live up to the relevant standards. (p.617)

Here it must be noted that 'surrogate accountability' cannot be a replacement for direct standard accountability whereby accountability holders are to account and impose appropriate sanctions for failure to discharge appropriate accountabilities. Rubenstein (2007) contends that it is generally inferior to standard accountability. In her paper it is instead proposed as the "second-best" form of accountability as opposed to no accountability at all. In the context of developing countries victims of corporate activities (e.g. workers and affected marginalised communities) can often find themselves unable to sanction the power wielders due to lack of power arising from prevalent inequalities, rampant corruption, weak governance and widespread poverty. These power differentials can often make direct standard accountability mechanisms ineffective leading to lack of accountability. We note that while these power differentials are unlikely to be resolved in the near future empowering the civil societies with a view to sanction the power wielders via surrogate accountability might be a reasonable way forward.

Civil societies which often represent the rights of the vulnerable stakeholders may act as a surrogate for the victims of globalised corporate activities and demand accountability from the corporations on behalf of the weaker constituents in developing countries. Civil societies can also prepare independent 'counter accounts' of the corporate activities with a view to expose an alternative form of corporate accountability of social and environmental impacts (Gray et al., 2014a). One example here could be the accounts produced by the NGO - Friends of the Earth (FoE, http://www.foe.co.uk/sites/default/files/downloads/failing challenge.pdf, accessed, 3 October, 2014) titled 'Failing the Challenge: The Other Shell Report' and published in 2003. The accounts, prepared in response to Shell's 2002 report, capture the voices of communities around the world affected by the global operations of Shell. It paints a different picture to the one that can be found in Shell's own report. In this case FoE acts as surrogate of the communities affected by Shell's activities around the world and imposes sanction on Shell via bad publicity and media exposure. These affected communities are otherwise unable, due to power differential, to hold power wielders like Shell to account via direct standard accountability mechanisms. Gray, Brennan, and Malpas (2014b) provide several other examples of similar 'counter accounts'.

\footnotetext{
${ }^{4}$ See Gallhofer et al. (2006) for an example of 'counter accounts' to achieve emancipatory potential of online reporting and Steiner (2010) for an alternative account of Shell's oil exploration activities in Nigeria and BP's oil spill in the Gulf of Mexico.
} 


\section{Brief Reflections on Accountability and Development-oriented CSR}

In the context of developing countries the contributions of global corporations have been mainly limited to employment generation and tax revenues to the national coffer. However, given the diminished roles of governments in developing countries modern businesses are urged to fulfil the developmental gaps left by such contraction of government roles. It is argued that a business cannot prosper in communities which fails due to widespread poverty (Pachauri, 2004, 2006). Business organisations tend to respond to this call by undertaking various community development activities in the areas of health, education and poverty alleviation (Eweje, 2006; Idemudia \& Ite, 2006; Ite, 2004; Sharmin, Khan, \& Belal, 2014). However, it should be borne in mind that these organisations are designed to maximise shareholders' wealth and whether they can ever fulfil the roles traditionally played by governments is a consideration beyond the scope of this chapter.

What we are seeing is that businesses are attempting to fulfil some of these contracted and retracted governmental roles via various development projects. This is normally done under the label of CSR. These CSR activities are often reported via CSR reports with the ambitious claims of promoting transparency and accountability. For example, the Bangladesh subsidiary of British American Tobacco made such claims in its Annual Report, 2002 (p.vi). However, majority of researches on social and environmental accounting so far have found evidences which are quite contrary to the above claims leading to the conclusion that this reporting is anything but an exercise of transparency and accountability (Cooper \& Owen, 2007). This necessarily brief reflection on development-oriented CSR shows that corporate potential to undertake CSR activities to help development agenda of the developing countries needs to be considered with caution and scepticism.

\section{Summary and Conclusion}

To summarise, in this chapter I argued that global corporate activities have created many benefits in the form of economic development of developing countries including employment generation and tax revenues for the state. However, social and environmental implications of these activities have not received adequate visibility in the corporate decision making and policy making arenas. I have provided some examples of these social and environmental consequences in this chapter from the context of a number of developing countries such as Bangladesh, Pakistan, Nigeria and Tanzania.

In conclusion it can be noted that while social and environmental accounting has the potential to raise the visibility of the social and environmental impacts of corporate activities it often fails to do so particularly under the current voluntary disclosure regime where corporations can choose what to report and how to report. I have argued for a possibility of 'surrogate accountability' (Rubenstein, 2007) led by the civil societies to hold the corporations to account. This is necessary due to lack of strong state governance and powerlessness of vulnerable stakeholders in the developing countries. It could also be argued that given the failure of current voluntary CSR reporting regimes urgent steps are necessary to reform the existing corporate governance structures to empower the non-shareholder stakeholders, particularly the victims of global corporate activities. This can be achieved by giving them a voice in the corporate decision making processes which affect these vulnerable stakeholders. 'Surrogate accountability' mechanism discussed above might be a way (but not the only one) to ensure that these voices are heard. 


\section{References}

Belal, A. R. (2002). Stakeholder accountability or stakeholder management: a review of UK firms' social and ethical accounting, auditing and reporting (SEAAR). Corporate Social Responsibility and Environmental Management, 9(1), 8-25.

Belal, A. R. (2008). Corporate Social Responsibility Reporting in Developing Countries: The Case of Bangladesh. Aldershot: Ashgate.

Belal, A. R., \& Cooper, S. (2011). The Absence of Corporate Social Responsibility Reporting in Bangladesh. Critical Perspectives on Accounting, 22(7), 654-667.

Belal, A. R., Cooper, S. \& Khan, N.A. (2015). Corporate environmental responsibility and accountability: What chance in vulnerable Bangladesh? Critical Perspectives on Accounting,

Forthcoming.

Belal, A. R., Cooper, S. M., \& Roberts, R. W. (2013). Vulnerable and exploitable: The need for organisational accountability and transparency in emerging and less developed economies. Accounting Forum, 37(2), 81-91.

Belal, A. R., \& Owen, D. (2007). The Views of Corporate Managers on the Current State of, and Future Prospects for, Social Reporting in Bangladesh: An Engagement Based Study. Accounting, Auditing \& Accountability Journal, 20(3), 472-494.

Cho, C. H. (2009). Legitimation Strategies Used in Response to Environmental Disaster: A French Case Study of Total S.A.'s Erika and AZF Incidents. European Accounting Review, 18(1), 3362.

Cho, C. H., \& Patten, D. M. (2007). The role of environmental disclosures as tools of legitimacy: A research note. Accounting, Organizations and Society, 32(7-8), 639-647.

Cooper, S. M., \& Owen, D. L. (2007). Corporate social reporting and stakeholder accountability: The missing link. Accounting, Organizations and Society, 32(7-8), 649-667.

Deegan, C. (2002). The legitimising effect of social and environmental disclosures - a theoretical foundation. Accounting, Auditing and Accountability Journal, 15(3), 282-311.

Deegan, C., Rankin, M., \& Tobin, J. (2002). An examination of the corporate social and environmental disclosures of BHP from 1983-1997: A test of legitimacy theory. Accounting, Auditing and Accountability Journal, 15(3), 312-343.

Derry, R. (2012). Reclaiming Marginalized Stakeholders. Journal of Business Ethics, 111(2), 253264.

EC. (2001). Green Paper: Promoting European Framework for Corporate Social Responsibility. Brussels: European Commission (EC).

Eden, L., \& Lenway, S. (2001). Introduction to the Symposium: Multinationals: The Janus face of Globalization. Journal of International Business Studies, 32(3), 383-400.

EIU. (2012, 27 October). Ship breaking in Bangladesh: Hard to break up.

Epstein, M. J., \& Buhovac, A. R. (2014). Making sustainability work: Best practices in managing and measuring corporate social, environmental, and economic impacts. Sheffield: Greenleaf Publishing.

Eweje, G. (2006). The Role of MNEs in Community Development Initiatives in Developing Countries. Business \& Society, 45(2), 93-129.

Gallhofer, S., Haslam, J., Monk, E., \& Roberts, C. (2006). The emancipatory potential of online reporting: the case of counter accounting. Accounting, Auditing \& Accountability Journal, 19(5), 681-718.

Gardner, K., Ahmed, Z., Bashir, F., \& Rana, M. (2012). Elusive Partnerships: Gas extraction and CSR in Bangladesh. Resources Policy, 37(2), 168-174.

Gifford, B., Kestler, A., \& Anand, S. (2010). Building local legitimacy into corporate social responsibility: Gold mining firms in developing nations. Journal of World Business, 45(3), 304-311. 
Gray, R., Adams, C., \& Owen, D. (2014a). Accountability, Social Responsibility and Sustainability: Accounting for Society and the Environment. Hemel Hempstead: Pearson Publishers.

Gray, R., Brennan, A., \& Malpas, J. (2014b). New accounts: Towards a reframing of social accounting. Accounting Forum, 38(4), 258-273.

Hossain, M., \& Islam, M. (2006). Ship Breaking Activities and its Impact on the Coastal Zone of Chittagong, Bangladesh: Towards Sustainable Management. Chittagong: Young Power in Social Action (YPSA)

Idemudia, U., \& Ite, U. E. (2006). Corporate-community relations in Nigeria's oil industry: challenges and imperatives. Corporate Social Responsibility and Environmental Management, 13(4),

Islam, M. A., \& Islam, M. A. (2011). Environmental incidents in a developing country and corporate environmental disclosures. Society and Business Review, 6(3), 229-248.

Ite, U. (2004). Multinationals and corporate social responsibility in developing countries: a case study of Nigeria. Corporate Social Responsibility and Environmental Management, 11(1), 1-11.

Jamali, D. (2010). The CSR of MNC subsidiaries in developing countries: global, local, substantive or diluted? Journal of Business Ethics, 93(2), 181-200.

Jamali, D., \& Mirshak, R. (2006). Corporate social responsibility (CSR): theory and practice in a developing country context. Journal of Business Ethics, 72(3), 243-262.

Kamal, Y., \& Deegan, C. (2013). Corporate Social and Environment-related Governance Disclosure Practices in the Textile and Garment Industry: Evidence from a Developing Country. Australian Accounting Review, 23(2), 117-134.

Khavul, S., \& Bruton, G. D. (2013). Harnessing Innovation for Change: Sustainability and Poverty in Developing Countries. Journal of Management Studies, 50(2), 285-306.

KPMG. (2013). KPMG International Survey of Corporate Responsibility Reporting 2013. Amsterdam: KPMG.

Lauwo, S., \& Otusanya, O. J. (2014). Corporate accountability and human rights disclosures: A case study of Barrick Gold Mine in Tanzania. Accounting Forum, 38(2), 91-108.

Matin, M. (1995). Environmental pollution and its control in Bangladesh. TRAC trends in analytical chemistry, 14(10), 468-473.

Maurice, J. (2001). Tannery pollution threatens health of half-million Bangladesh residents Bulletin of the World Health Organization, 79(1), 78-79. Retrieved April 29, 2014, from http://www.scielosp.org/scielo.php?script=sci_arttext\&pid=S004296862001000100018\&lng=en\&tlng=en. 10.1590/S0042-96862001000100018.

McKinsey. (2011). Bangladesh's ready-made garments landscape: The challenge of growth. Germany: McKinsey and Company.

Medawar, C. (1976). The social audit: A political view. Accounting, Organizations and Society, 1(4), 389-394.

Miller, D. (2013, 14th May). World's biggest ship graveyard - where huge tankers and cruise liners are scrapped on the shorefront and workers toil for $£ 2$ a day. Mail Online. Retrieved from Read more: http://www.dailymail.co.uk/news/article-2324339/Worlds-biggest-ship-graveyard-huge-tankers-cruise-liners-scrapped-shorefront-workers-toil-2-day.html\#ixzz30NQx5hKK

Motlagh, J. (2013, 3 September). Hell for Leather: Bangladesh's Toxic Tanneries Ravage Lives and Environment. Time Magazine.

Nasreen, M., Mokaddem Hossain, K., \& Kumar Kundu, D. (2006). The Interrelationship between Poverty, Environment and Sustainable Development in Bangladesh: An Overview. Bangladesh e-Journal of Sociology, 3(2), 1-21.

Newenham-Kahindi, A. (2011). A Global Mining Corporation and Local Communities in the Lake Victoria Zone: The Case of Barrick Gold Multinational in Tanzania. Journal of Business Ethics, 99(2), 253-282.

Pachauri, R. K. (2004, 22 December). The rationale for corporate social responsibility in India. The Financial Express. from http://www.teriin.org/articles 
Pachauri, R. K. (2006, 28 April). CSR in new dimensions. The Economic Times. Retrieved from http://www.teriin.org/articles

Renton, A. (2012, 13 December 2012). Bangladesh's toxic tanneries turning a profit at an intolerable human price. The Guardian.

Rubenstein, J. (2007). Accountability in an unequal world. Journal of Politics, 69(3), 616-632.

Saha, P. S. (2014, 10 March). Pollution affected neighbourhood. Prothom Alo.

Sharmin, S., Khan, N. A., \& Belal, A. R. (2014). Corporate Community Involvement In Bangladesh: An Empirical Study. Corporate Social Responsibility and Environmental Management, 21(1), 41-51.

Siddiqui, J. (2001). Environmental non-accountability in Bangladesh?: The striking case of the Magurchara gas field disaster. Social and Environmental Accountability Journal, 21(2), 12-13.

Sikka, P. (2008). Globalization and its discontents. Accounting, Auditing \& Accountability Journal, 21(3), 398-426.

Sikka, P. (2011). Accounting for human rights: The challenge of globalization and foreign investment agreements. Critical Perspectives on Accounting, 22(8), 811-827.

Steiner, R. (2010). Double standard: Shell practices in Nigeria compared with international standards to prevent and control pipeline oil spills and the Deepwater Horizon oil spill. Amsterdam: Friends of the Earth.

Unerman, J. (2003). Enhancing organisational global hegemony with narrative accounting disclosures: an early example. Accounting Forum, 27(4), 425-448.

Yardley, J. (2013, 14 July). Bangladesh Pollution, Told in Colors and Smells. NY Times. 